\title{
Growth Performance and Cultivation of Four Oyster Mushroom Species on Sawdust and Rice Bran Substrates
}

\author{
Mustafa Nadhim Owaid ${ }^{1,2 *}$, Sajid Salem S. Al-Saeedi², Vikineswary Sabaratnam ${ }^{3}$, \\ Idham Abed Ali Al-Assaffii ${ }^{4}$, Jegadeesh Raman ${ }^{3}$ \\ ${ }^{1}$ Al-Athar Secondary School, Heet Education, Ministry of Education, Heet, Anbar 31007, Iraq \\ mustafa@alheeti.com \\ ${ }^{2}$ Department of Biology, College of Science, University of Anbar, Ramadi, Anbar 31001, Iraq \\ saggedalseaidy@yahoo.com \\ ${ }^{3}$ Mushroom Research Centre, Institute of Biological Sciences, Faculty of Science, University of Malaya, 50603 \\ Kuala Lumpur, Malaysia \\ viki@um.edu.my \\ ${ }^{4}$ Department of Soil and Water, College of Agriculture, University of Anbar, Ramadi, Anbar 31001, Iraq \\ assaffii2004@yahoo.com
}

\begin{abstract}
Pleurotus species are progressively becoming important edible mushrooms worldwide and it is of importance in choosing suitable substrates in a given place to grow them. The study provides basic and valuable information on mycelial growth rates and yield efficacy of four different Pleurotus spp. The highest average mycelium growth of $1.29 \mathrm{~mm} / \mathrm{day}$ followed by $1.17 \mathrm{~mm} /$ day was observed in the bags of $P$. salmoneostramineus and $P$. ostreatus grey, respectively. Similarly, the highest cumulative growth of $12.90 \mathrm{~cm} /$ day and $11.74 \mathrm{~cm} /$ day was recorded in the 30 day old bags of $P$. salmoneostramineus and $P$. ostreatus grey, respectively. There was a significant increase $(P<0.05)$ of about three fold in the pin head formation of $P$. ostreatus grey (9 days) compared to other mushroom species (2-3 days). $P$. salmoneostramineus showed a vigorous growth in the fruiting body and the harvesting time required was just 5.67 days. It is clear from the result that there is no correlation between the rate of mycelia growth and pin appearance. The yield varied significantly due to the effect of mycelial growth on the substrate. The highest first flush and number of fruiting bodies was achieved in the yellow oyster followed by $P$. ostreatus grey and $P$. salmoneostramineus. In conclusion, sawdust and rice bran could be a promising substrate for linear mycelial growth of $P$. ostreatus species.
\end{abstract}

\section{Indexing terms/Keywords}

Mycelium Linear Growth, Oyster mushrooms, sawdust, rice bran, bags.

\section{Academic Discipline And Sub-Disciplines}

Biotechnology

\section{SUBJECT CLASSIFICATION}

Cultivation

\section{TYPE (METHOD/APPROACH)}

Experimental.

\section{Council for Innovative Research}

Peer Review Research Publishing System

\section{Journal: JOURNAL OF ADVANCES IN BIOTECHNOLOGY}

Vol. 4, No. 3

www.ciribt.org , jbteditor@gmail.com 


\section{INTRODUCTION}

The ever growing need of producing cheap nutritious food, led to the fast development of the mushroom cultivation industry [1]. The current market is eagerly looking for the introduction of new mushroom products through the cultivation of exotic species, which provides an array of novel choices for the consumer and promotes social development [2, 3]. The large quantities of agro-industrial wastes that are produced world-wide often cause environmental problems associated with their safe disposal. However, the problem could be resolved using edible mushroom species, which possess an appropriate enzymatic mechanism to bioconvert lignocellulosic wastes into value-added products such as food, fodder or plant fertilizer $[4,5]$.

The fungus Pleurotus also called as oyster mushroom belongs to the phylum Basidiomycota, class: Agaricomycetes, family: Pleurotaceae [6]. The oyster mushrooms are the second most important mushrooms cultivated across the world, accounting for $25 \%$ of total world production of cultivated mushrooms [7]. Cultivation of the oyster mushroom, Pleurotus spp., has increased greatly throughout the world during the last few decades [8, 9]; in 1997 it accounted for $14.2 \%$ of the total world mushroom production. Its popularity has been increasing due to its ease of cultivation, high yield potential and high nutritional value [10]. Although, commonly grown on pasteurized wheat, rice straw and sawdust, it can be cultivated on a wide variety of lignocellulosic substrates, enabling it to play an important role in managing organic wastes [11, 12]. Oyster mushroom species are known to produce lignolytic and hydrolytic enzymes and they can therefore be adapted for growth within a wide variety of lignocellulosic wastes with an increase in the availability of carbohydrates and biomass accumulation [13].

A linear mycelial growth test was used to measure the average mycelium growth in the cultivation of Lentinula edodes with sunflower seed halls substrate in combination with different ratios of wheat bran, poplar sawdust or oat straw [14]. The recent study on mycelial linear growth was performed by Lin-Zhi et al. [15] on Flammulina velutipes. Thus, reducing the time required for the culture cycle is necessary to decrease production costs. Therefore, methods that increase either mycelium growth or fructification are of interest. The study was undertaken to evaluate the linear growth and yield of four different Pleurotus spp. (Pleurotus ostreatus white, Pleurotus ostreatus grey, Pleurotus cornucopiae var. citrinopileatus and Pleurotus salmoneostramineus) mushroom on easily available sawdust with rice brawn.

\section{MATERIALS AND METHODS}

\section{Mushrooms Sampling and Collection}

Four different oyster mushrooms namely Pleurotus ostreatus (grey oyster), Pleurotus ostreatus (white oyster), Pleurotus cornucopiae var. citrinopileatus (bright yellow oyster) and Pleurotus salmoneostramineus (pink oyster) were collected from plant pathology and fungi lab, College of Science, University of Anbar, Iraq. Four different Pleurotus spp. were established by tissue culture technique [16]. The mycelia were propagated and maintained on Potato Dextrose agar medium [17] and incubated at $25 \pm 1^{\circ} \mathrm{C}$ for $6 \mathrm{~d}$.

\section{Spawn Preparation}

One kg of healthy grains of wheat (Triticum vulgare) was washed thoroughly in tap water and soaked overnight with water till they become soft. One hundred grams each of these grains was taken in $250 \mathrm{ml}$ conical flasks plugged with cotton and sterilized at $15 \mathrm{lbs}$ of pressure for $20 \mathrm{~min}$. After cooling at room temperature, they were inoculated with $10 \mathrm{~mm}$ disc of pure cultures. The flasks were incubated at $25 \pm 1^{\circ} \mathrm{C}$ in dark [18].

\section{Substrates Preparation}

Sawdust and rice bran used as a solid substrate for mushroom cultivation. The $89.8 \%$ sawdust, $10 \%$ rice bran and $0.2 \%$ $\mathrm{CaCO} 3$ was mixed, added water and keep overnight. The excess water was drained out and the substrates were transferred in to $(30 \mathrm{~cm} \times 10 \mathrm{~cm})$ polypropylene bags of one $\mathrm{kg}$. The bags were sterilized for $30 \mathrm{~min}$ at $15 \mathrm{lb} / \mathrm{sq}$ inch pressure. After cooling the substrate, each different mushrooms spawn was inoculated separately in triplicate. The inoculated mushroom bags were incubated for one month at $25^{\circ} \mathrm{C}[19]$.

\section{Linear Mycelial Growth Test (LMG Test)}

The linear growth was determined every three days until 30 days. The cumulative growth and periodic growth in 3 days interval were determined according to Saidu et al. [20].

\section{Cropping and Harvesting}

As soon as the mycelia growth has covered the whole substrate, the bags were transferred into mushroom shed. The transferred mushroom bags were placed on the racks to expose light intensity of around 2000-3000 lux units for fruiting bodies development. The cultivation room and the substrate were maintained at $80-90 \%$ humidity by regularly spraying of water twice a day. Pin heads were formed after 2-4 days and the fruiting bodies were harvested at the right stage and the beds were again maintained for second and third cropping (Figure 1).

\section{Statistical Analysis}

Experimental values are given as means. Statistical significance was determined by one variance (One Way) analysis (ANOVA) by using GenStat Discovery Edition computer program version 7 DE3 (VSN International Ltd., UK). Differences at $P<0.05$ were considered to be significant. The experiments were used three replicates. 


\section{RESULTS AND DISCUSSION}

The effect of solid substrate (Sawdust and rice bran) on mycelial growth of Pleurotus ostreatus (grey oyster), $P$. ostreatus (white oyster), $P$. cornucopiae var. citrinopileatus (bright yellow oyster) and $P$. salmoneostramineus (pink oyster) is shown in Table 1. Mycelial growth reached its maximum growth on 30th day recorded by visual observation (Fig. 1). The effect of the solid substrate fermentation and mycelial growth varied according to mushroom species. Sawdust and rice brawn has been referred as the most commonly used solid substrate for mushroom production and it is usually offered for the best results in studies on $P$. eryngii [21].

Table 1. Mycelial growth assessment and yield of fruiting bodies on solid substrate

\begin{tabular}{|l|l|l|l|l|l|l|l|}
\hline $\begin{array}{l}\text { Oyster } \\
\text { mushrooms }\end{array}$ & $\begin{array}{l}\text { Average of } \\
\text { growth } \\
(\mathrm{mm} / \mathrm{day})\end{array}$ & $\begin{array}{l}\text { Cumulative } \\
\text { growth in } \\
30 \text { days } \\
(\mathrm{cm})\end{array}$ & $\begin{array}{l}\text { Pin appear } \\
\text { date (day) }\end{array}$ & $\begin{array}{l}\text { Fruiting } \\
\text { harvested } \\
\text { date }\end{array}$ & $\begin{array}{l}\text { Weight of } \\
\text { first flush } \\
(\mathrm{g})\end{array}$ & $\begin{array}{l}\text { Average } \\
\text { number of } \\
\text { fruit bodies }\end{array}$ & $\begin{array}{l}\text { Average } \\
\text { weight of } \\
\text { fruit body } \\
(\mathrm{g})\end{array}$ \\
\hline Grey & 1.17 & 11.74 & 9.00 & 11.33 & 93.8 & 15.5 & 7.04 \\
\hline White & 1.00 & 9.99 & 3.00 & 9.33 & 99.2 & 21.3 & 4.83 \\
\hline Yellow & 0.78 & 7.82 & 3.00 & 10.00 & 141.0 & 41.0 & 3.44 \\
\hline Pink & 1.29 & 12.90 & 2.00 & 5.67 & 96.9 & 11.0 & 9.23 \\
\hline $\begin{array}{l}\text { LSD P< } \\
\mathbf{0 . 0 5}\end{array}$ & $\mathbf{0 . 3 3 3}$ & $\mathbf{3 . 3 2 1}$ & $\mathbf{0 . 9 4 1}$ & $\mathbf{0 . 9 4 1}$ & $\mathbf{2 5 . 8 3}$ & $\mathbf{1 0 . 4 2}$ & $\mathbf{3 . 3 9 2}$ \\
\hline
\end{tabular}

The highest average mycelium growth of $1.29 \mathrm{~mm} /$ day followed by $1.17 \mathrm{~mm} /$ day was observed in the bags of $P$. salmoneostramineus and $P$. ostreatus grey, respectively. Similarly, the highest cumulative growth of $12.90 \mathrm{~cm} /$ day and $11.74 \mathrm{~cm} /$ day was recorded in the 30 day old bags of $P$. salmoneostramineus and $P$. ostreatus grey, respectively (Fig. 3 \& 4). A recent study recorded the maximum mycelium linear growth of $8.9 \mathrm{~mm} /$ day when cultivating king oyster $P$. eryngii on substrate consisting of rice bran, sawdust, soybean straw and rice straw [21].

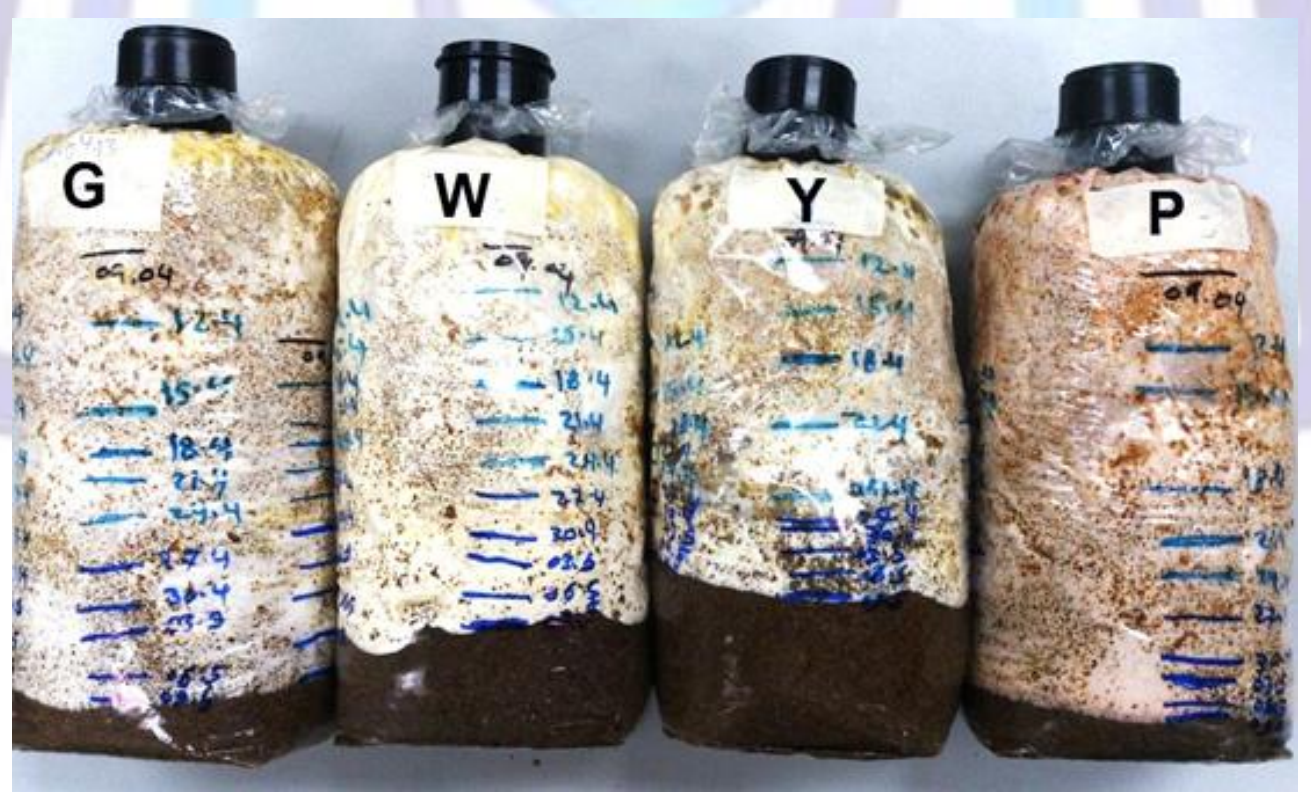

G: $P$. ostreatus (grey oyster), W: $P$. ostreatus (white oyster), Y: $P$. cornucopiae var. citrinopileatus (bright yellow oyster), P: $P$. salmoneostramineus (pink oyster)

Figure 2. Linear mycelial growth of oyster mushrooms in bags (1 kg, wet weight) after 30 days incubation 


\section{ISSN 2348-6201}

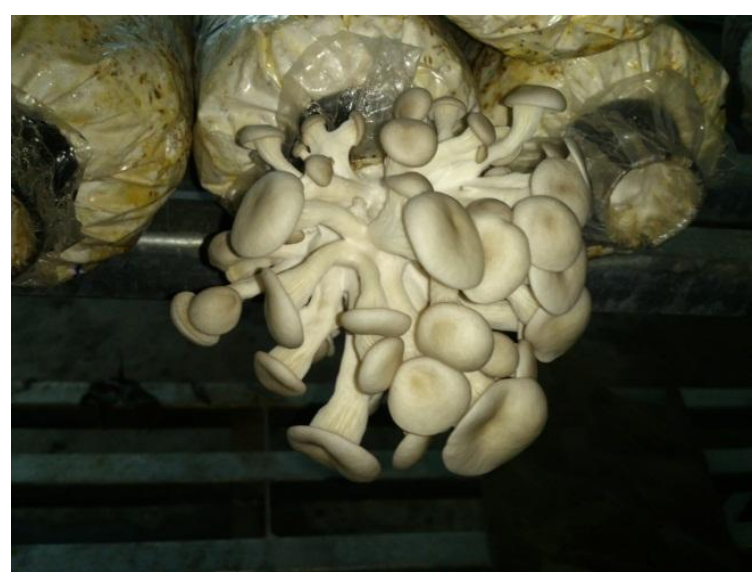

P. ostreatus (grey)

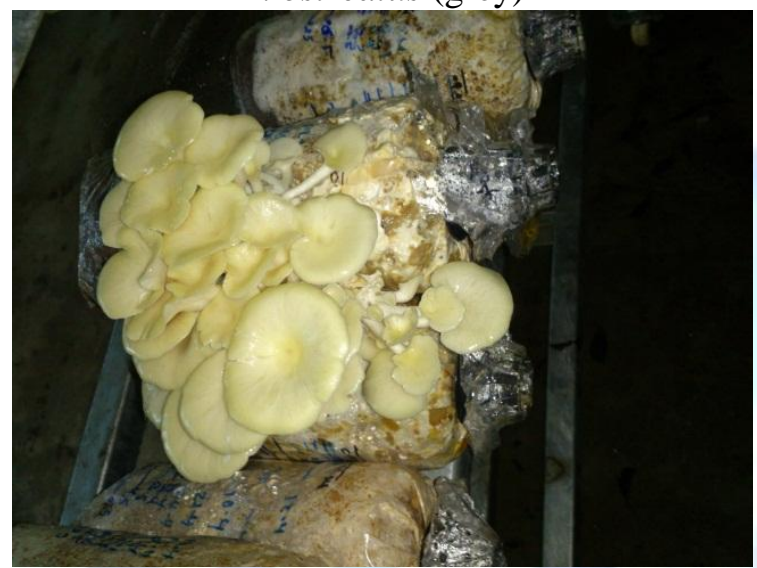

P. cornucopiae var. citrinopileatus (bright yellow)

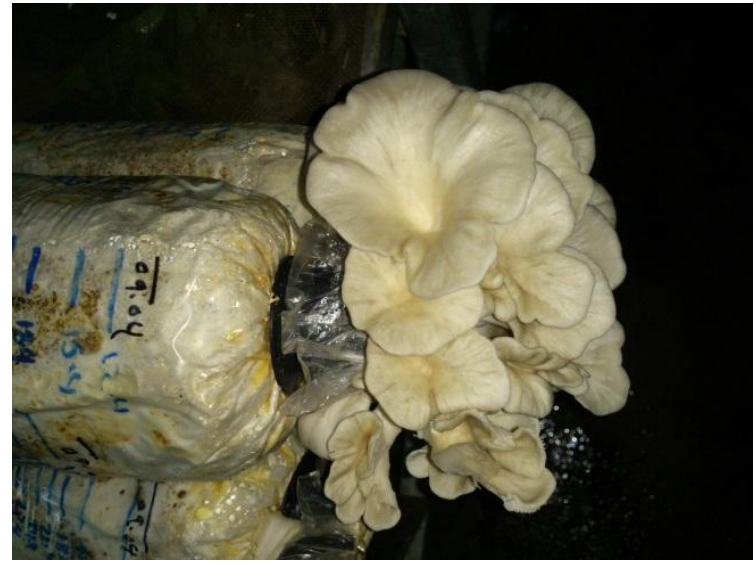

P. ostreatus (white)

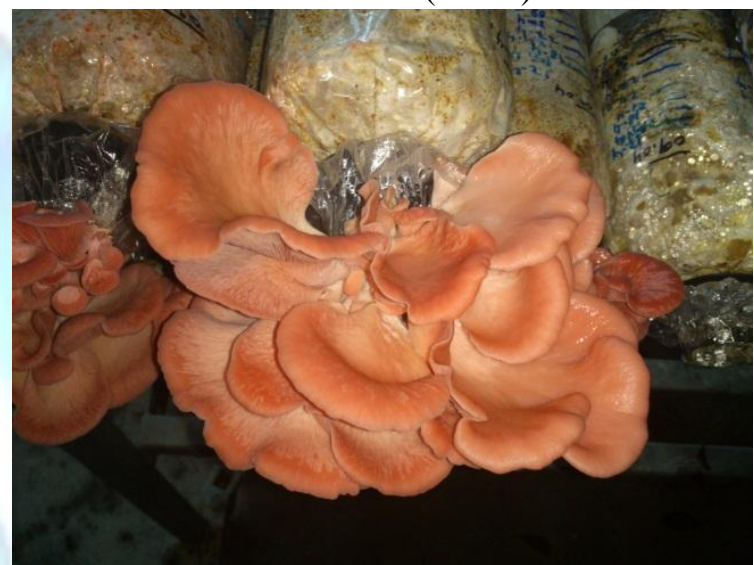

P. salmoneostramineus (pink)

Figure 2. Fruiting body emerging on solid substrate

There was a significant increase $(P<0.05)$ of about three fold in the pin head formation of $P$. ostreatus grey (9 days) compared to other mushroom species (2-3 days). Ahmed et al. [22] reported that pin head formation took seven to ten days after the completion of spawn running in Pleurotus spp. Obodai et al. [23] reported that pinhead formation took four to six days after the completion of spawn running, with harvest after 10 to 12 days in the case of $P$. ostreatus on different substrate. It is clear that the substrates used in the current study were superior compared to earlier published studies.

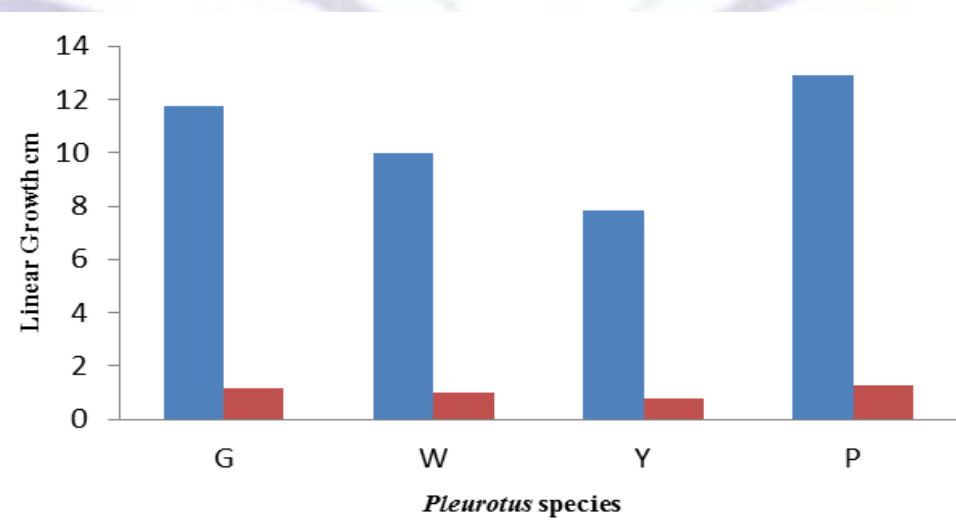

- Cumulative Growth (cm) $\quad$ Growth Rate (mm/day)

Figure 3. Linear mycelia growth of different oyster mushroom species 


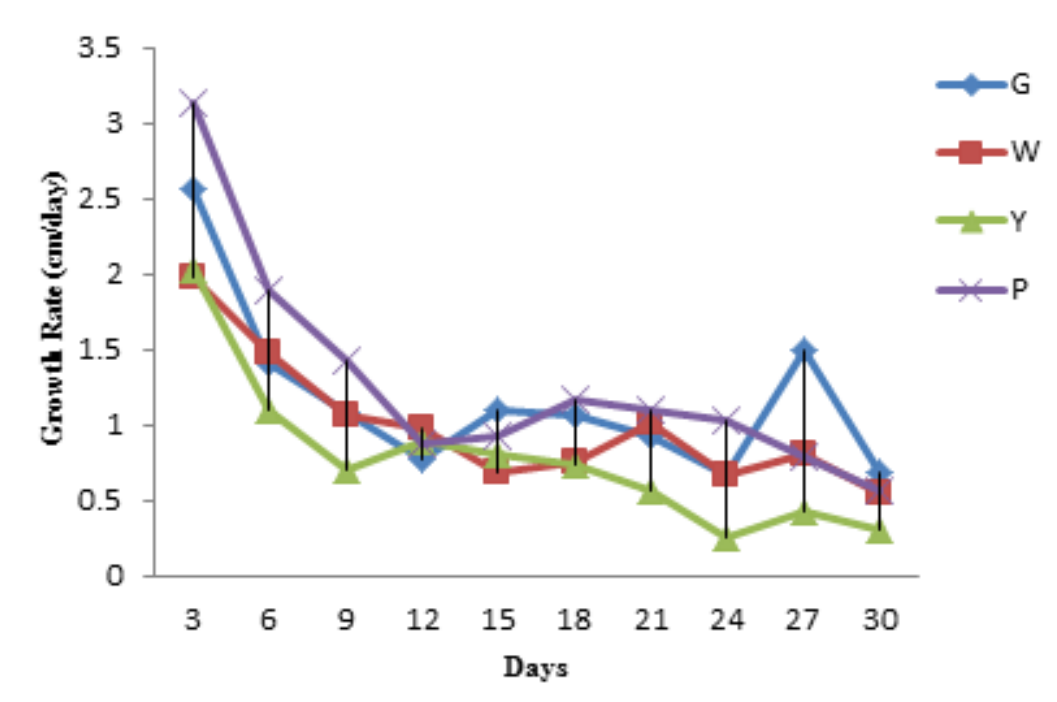

Figure 4. Linear mycelial growth rate of four different oyster mushroom species on solid substrate

Comparing the fruiting body harvesting time of all the four mushroom species, $P$. salmoneostramineus showed a vigorous growth in the fruiting body and the harvesting time required was just 5.67 days. Whereas other species took a longer time (9.33 days for $P$. ostreatus white, 10 days for $P$. cornucopiae var. citrinopileatus, and 11.33 days for $P$. ostreatus grey). It is evident from the result that there is no correlation between the rate of mycelia growth and pin appearance. In line with our result, Shukla and Jaitly, [24] have observed similar negative correlation and reported that genetic diversity may play a key role on the mushroom production. Similarly, Kashangura, [25] reported that the primordial initiation and crop production depends on the species and substrate mixture (Table 2).

Table 2. The correlation between characteristics

\begin{tabular}{|l|l|l|l|l|l|l|l|}
\hline $\begin{array}{l}\text { Oyster } \\
\text { mushrooms }\end{array}$ & $\begin{array}{l}\text { Average of } \\
\text { growth } \\
(\mathrm{mm} / \text { day) }\end{array}$ & $\begin{array}{l}\text { Cumulative } \\
\text { growth in } \\
30 \text { days } \\
(\mathrm{cm})\end{array}$ & $\begin{array}{l}\text { Pin appear } \\
\text { date (day) }\end{array}$ & $\begin{array}{l}\text { Fruiting } \\
\text { harvested } \\
\text { date }\end{array}$ & $\begin{array}{l}\text { Weight of } \\
\text { first flush } \\
(\mathrm{g})\end{array}$ & $\begin{array}{l}\text { Average } \\
\text { number of } \\
\text { fruit bodies }\end{array}$ & $\begin{array}{l}\text { Average } \\
\text { weight of } \\
\text { fruit body } \\
(\mathrm{g})\end{array}$ \\
\hline Grey & 1.17 & 11.74 & 9.00 & 11.33 & 93.8 & 15.5 & 7.04 \\
\hline White & 1.00 & 9.99 & 3.00 & 9.33 & 99.2 & 21.3 & 4.83 \\
\hline Yellow & 0.78 & 7.82 & 3.00 & 10.00 & 141.0 & 41.0 & 3.44 \\
\hline Pink & 1.29 & 12.90 & 2.00 & 5.67 & 96.9 & 11.0 & 9.23 \\
\hline $\begin{array}{l}\text { LSD P< } \\
\mathbf{0 . 0 5}\end{array}$ & $\mathbf{0 . 3 3 3}$ & $\mathbf{3 . 3 2 1}$ & $\mathbf{0 . 9 4 1}$ & $\mathbf{0 . 9 4 1}$ & $\mathbf{2 5 . 8 3}$ & $\mathbf{1 0 . 4 2}$ & $\mathbf{3 . 3 9 2}$ \\
\hline
\end{tabular}

The yield varied significantly due to the effect of mycelial growth on the substrate. The highest first flush and number of fruiting bodies was achieved in the yellow oyster followed by $P$. ostreatus grey and $P$. salmoneostramineus (Fig. 2 and Table 1).

In conclusion, sawdust and rice bran could be a promising substrate for linear mycelial growth of $P$. ostreatus species. The pin appearance time depends mainly on genetic factors of the mushroom species.

\section{ACKNOWLEDGMENTS}

Support for this research by Research Scholarships Programme No. 12/29861 on 12/2012 at foreign universities in Ministry of Higher Education and Scientific Research, Scholarships \& Cultural Affairs Directorate, Iraq is gratefully acknowledged to complete this work in MRC, University of Malaya, KL, Malaysia.

\section{REFERENCES}

[1] Zervakis, O., Philippoussis, A., loannidou, S. and Diamantopoulou, P. 2001. Mycelium growth kinetics and optimal temperature conditions for the cultivation of edible mushroom species on Lignocellulosic substrates. Folia Microbiologica. 46: 231-234.

[2] Philippoussis, A. and Zervakis, G. 2000. Cultivation of edible mushrooms in Greece: presentation of the current status and analysis of future trends. In L. Van Griensven (Ed.): Proc. 15th Internat. Congr. Science and Cultivation of Edible Fungi. Balkema, Rouerdam (Netherlands), pp. 843-848. 
[3] Zervakis, G. and Venturella, G. 2000. Mushroom breeding and cultivation favors ex situ conservation of Mediterranean Pleurotus taxa. Proc, Internat Conf. Science and Technology for Managing Plant Genetic Diversity in the 21st Century. IPGRI, Kuala Lumpur (Malaysia).

[4] Philippoussis, A., Diamantopoulou, P., Zervakis, G. and loannidou, S. 2000. Potential for the cultivation of exotic mushroom species by exploitation of Mediterranean agricultural wastes. In L. Van Griensven (Ed.): Proc. 15th Internat. Congr. Science and Cultivation of Edible Fungi. Balkema, Rotterdam (Netherlands), pp. 523-530.

[5] Poppe, J. 2000. Use of agricultural waste materials in the cultivation of mushrooms. In L. Van Griensven (Ed.): Proc. 15th Internat. Congr. Science and Cultivation of Edible Fungi. Balkema, Rotterdam (Netherlands), pp. 3-23.

[6] Vilgalys, R. and Sun, B. L. 1994. Rapid genetic identification and mapping of enzymatically amplified ribosomal DNA from several Cryptococcus species. Journal of Bacteriology. 172: 4238-4246.

[7] Vasudewa, N. S., Abeytunga1, D. T. U. and Ratnasooriya, W. D. 2007. Antinociceptive activity of Pleurotus ostreatus, an edible mushroom, in rats. Pharmaceutical Biology. 45: 533-540.

[8] Chang, S. T. 1999. World production of cultivated and medicinal mushrooms in 1997 with emphasis on Lentinus edodes (Berk.) Sing, China. International Journal of Medicinal Mushrooms. 1: 291-300.

[9] Royse, D. J. 2002. Influence of spawn rate and commercial delayed release nutrient levels on Pleurotus cornucopiae (oyster mushroom) yield, size and time to production. Applied Microbiology and Biotechnology. 58: 527-531.

[10] Banik, S. and Nandi, R. 2004. Effect of supplementation of rice straw with biogas residual slurry manure on the yield, protein and mineral contents of oyster mushroom. AZ. 20: 311-319.

[11] Kabirifard, A., Fazaeli, H. and Kafilzadeh, F. 2012. Comparison of growth rate of four Pleurotus fungi species on wheat straw and date palm leaf. Journal of Research in Agricultural Sciences. 8: 35-43.

[12] Kulshreshtha, S., Mathur, N., Bhatnagar, P. and Kulshreshtha, S. 2013. Cultivation of Pleurotus citrinopileatus on handmade paper and cardboard industrial wastes. Industrial Crops and Products. 41: 340-346.

[13] Mikiashvili, N., Wasswe, S. P., Nevo, E. and Elisashvili, V. 2006. Effects of carbon and nitrogen sources on Pleurotus ostreatus ligninolytic enzyme activity. World Journal of Microbiology and Biotechnology. 22: 999-1002.

[14] Curvetto, N., Figlas, D. and Delmastro, S. 2002. Sunflower seed hulls as substrate for the cultivation of shiitake mushrooms. Research Report. 12: 652-655.

[15] Lin-Zhi, K., Fei, H., Jun-Fang, L., Li-Qiong, G. and Wei-Fang, B. 2013. Breeding of new high-temperature-tolerant strains of Flammulina velutipes. Scientia Horticulturae. 151: 97-102.

[16] Chang, S. T. and Miles, P.G. 2004. Mushrooms: cultivation, nutrition value, medicinal effect and environmental impact. Second ed. CRC Press, 389 pp.

[17] Difco Manual, 1953. Difco manual of dehydrated culture media and reagents for microbiological and clinical laboratory procedures (9th ed.), Difco Laboratories, Detroit.

[18] Hanko, J. 2001. Mushroom Cultivation for People with Disabilities: A Training Manual. Regional Office for Asia and the Pacific. FAO.

[19] Biswas, S., Datta, M. and Ngachan, S. V. 2012. Mushrooms: A Manual for Cultivation. PHI Learning Pvt. Ltd., New Delhi, India, pp. 85.

[20] Saidu, M., Salim, M.R. and Yuzir, M. A. M. 2011. Cultivation of oyster mushroom (Pleurotus spp.) on palm oil mesocarp fibre. African Journal of Biotechnology. 10: 15973-15976.

[21] Hassan, F. R. H., Medany, G. M. and Abou Hussein, S. D. 2010. Cultivation of the king oyster mushroom (Plerrotus eryngii) in Egypt. Australian Journal of Basic and Applied Sciences. 4: 99-105.

[22] Ahmed, M., Abdullah, N., Ahmed, K. U. and Bhuyan, M. H. M. B. 2013. Yield and nutritional composition of oyster mushroom strains newly introduced in Bangladesh. Pesquisa Agropecuária Brasileira. 48: 197-202.

[23] Obodai, M., Cleland-Okine, J. and Vowotor, K. A. 2003. Comparative study on the growth and yield of Pleurotus ostreatus mushroom on different lignocellulosic by-products. Journal of Industrial Microbiology and Biotechnology. 30: 146-149.

[24] Shukla, S. and Jaitly, A. K. 2011. Morphological and biochemical characterization of different oyster mushroom (Pleurotus spp.). Journal of Phytology. 3: 18-20.

[25] Kashangura, C. 2008. Optimisation of the growth conditions and genetic characterisation of Pleurotus species. Ph.D. Thesis. Department of Biological Sciences, Faculty of Science, University of Zimbabwe, pp. 152. 